\title{
Clinical management of women in BRCAX families: issues and controversies
}

G Mitchell

From Familial Aspects of Cancer 2011 Research and Practice: A combined meeting of kConFab, Australian Breast Cancer Family Study, Australian Colorectal Cancer Family Study, Australian Ovarian Cancer Study, Family Cancer Clinics of Australia and New Zealand and kConFab

Kingscliff, Australia. 23-26 August 2011

The role of the familial cancer clinic (FCC) is to provide a cancer risk assessment and appropriate cancer risk management advice, but there are certain groups of patients for whom there are no standard risk management guidelines. One such group is women with a strong family history of breast cancer but BRCA genetic testing has not found a germline mutation. As a family history of breast cancer is the commonest reason for referral to FCCs, this clinical scenario is a frequent challenge to us all.

This presentation will provide a summary of the literature surrounding:

- Breast cancer risk in BRCAX families

- Ovarian cancer risk in BRCAX families

- Does the presence of male breast cancer affect the breast and ovarian cancer risks for women in BRCAX families

Published: 12 April 2012

doi:10.1186/1897-4287-10-S2-A

Cite this article as: Mitchell: Clinical management of women in BRCAX families: issues and controversies. Hereditary Cancer in Clinical Practice 2012 10(Suppl 2):A1

Family Cancer Clinic, Peter MacCallum Cancer Centre, East Melbourne, 3002, Australia

(c) 2012 Mitchell; licensee BioMed Central Ltd. This is an Open Access article distributed under the terms of the Creative Commons Attribution License (http://creativecommons.org/licenses/by/2.0), which permits unrestricted use, distribution, and reproduction in any medium, provided the original work is properly cited.
Submit your next manuscript to BioMed Central and take full advantage of:

- Convenient online submission

- Thorough peer review

- No space constraints or color figure charges

- Immediate publication on acceptance

- Inclusion in PubMed, CAS, Scopus and Google Scholar

- Research which is freely available for redistribution

Submit your manuscript at www.biomedcentral.com/submit 